\title{
The Guanidine Pseudoalkaloids 10-Methoxy-Leonurine and Leonurine Act as Competitive Inhibitors of Tyrosinase
}

\author{
Jang Hoon Kim ${ }^{1} * \mathbb{D}$, Hyun Hee Leem ${ }^{2}$ and Ga Young Lee ${ }^{3, *}$ \\ 1 Research Institute for Basic Sciences, JeJu National University, Jeju 63243, Korea \\ 2 National Development Institute of Korean Medicine, Gyeongsan 38573, Korea; npb0391@nikom.or.kr \\ 3 Hephzibah Korea Lnc, Techno 10-ro, Yuseong-gu, Daejeon 34036, Korea \\ * Correspondence: oasis5325@gmail.com (J.H.K.); gylee6409@gmail.com (G.Y.L.); \\ Tel.: +82-64-754-8308 (J.H.K.); +82-42-935-9944 (G.Y.L.)
}

Received: 24 December 2019; Accepted: 22 January 2020; Published: 23 January 2020

\begin{abstract}
Tyrosinase plays a key role in the production of melanin. A variety of industrial fields have shown interest in the development of tyrosinase inhibitors from plants. In this study, compounds 1-5 derived from Leonurus japonicas were evaluated to determine their ability to inhibit tyrosinase. Of these, 10-methoxy-leonurine (1) and leonurine (2) exhibited $\mathrm{IC}_{50}$ values of $7.4 \pm 0.4$ and $12.4 \pm 0.8 \mu \mathrm{M}$, respectively, and acted as competitive inhibitors of tyrosinase, with Ki values in the micromolar range. In silico modeling revealed a guanidine group located in the inner cavity and a benzene ring docked within the active site of these compounds. These guanidine pseudoalkaloids show potential not only as tyrosinase inhibitors but also as lead compounds in new scaffolds for the development of novel inhibitors.
\end{abstract}

Keywords: Leonurus japonicas; guanidine pseudoalkaloid; tyrosinase; competitive inhibitor; lead compound

\section{Introduction}

Tyrosinase (EC 1.14.18.1), found in bacteria, fungi, plants, and mammals [1], is a copper-containing metalloenzyme with various catalytic functions, such as hydroxylation of monophenols and oxidation of diphenols, which are important for the production of melanin pigment [2]. Excessive accumulation of melanin is responsible not only for pigment disorders in human skin but also enzymatic browning of fresh-cut fruits and vegetables [3]. It is also important for cuticle formation in insects [4]. Inhibiting the production of melanin precursors to prevent the undesirable effects of melanin is considered an important strategy [4]. As a result, tyrosinase is regarded as a target enzyme for the development of whitening agents, food preservatives, and agricultural insecticides [5]. In addition, tyrosinase inhibitors have been also proposed as neuroprotective agents [6]. Recently, secondary metabolites isolated from natural products, such as aloe-emodin [4], broussoflavonol J, broussoflavonol H [7], and calycosin [8], have been evaluated as tyrosinase inhibitors because of their low toxicities.

Leonurus japonicas is a perennial herb of the Labiatae family widely distributed in Asia [9]. This plant, which is referred to as "Yi Mu Cao" in traditional Chinese medicine, has been used to treat menoxenia, dysmenorrhea, amenorrhea, and ulcerations [10]. Phytochemical investigation of L. japonicas has led to the isolation of a variety of compounds from this plant by column chromatography, including ladbane diterpenes [11], phenylethanoid glycosides [12], steroids [13], alkaloids [14], and flavonoid glycosides [14]. Among the isolated compounds isolated, studies showed that leojaponin inhibited melanin production in B16F10 melanoma cells [15], and that phenylethanoid glycosides exerted hepatoprotective activity similar to that of bicyclol in HL-7702 cells [12]. 
The objective of this study was to evaluate the inhibitory activities of compounds from L. japonicas on tyrosinase. The pseudoalkaloids 10-methoxy-leonurine and leonurine, at micromolar concentrations, were revealed to be potential inhibitors of tyrosinase. These compounds disrupt the catalytic reactions of tyrosinase by binding to its active site. Molecular docking simulations showed that these compounds fit into the active site of the enzyme. Thus, pseudoalkaloids may be lead candidates for the development of tyrosinase inhibitors from L. japonicas.

\section{Materials and Methods}

\subsection{General Experimental Procedures}

ESI-MS spectra were recorded on a microTOF-QTM II (Bruker, Billerica, MA., USA). NMR experiments were conducted on an ECA500 (JEOL, Tokyo, Japan), with the chemical shift referenced to the residual solvent signals. TLC analysis was performed on Kieselgel 60 F254 (Merck, Darmstadt, Hesse, Germany) plates (silica gel, $0.25 \mathrm{~mm}$ layer thickness), single compounds were visualized by dipping plates into $10 \%(v / v) \mathrm{H}_{2} \mathrm{SO}_{4}$ reagent (Aldrich), and then dried air heat treated at $300{ }^{\circ} \mathrm{C}$ for $30 \mathrm{~s}$. Silica gel (Merck 60A, 70 to 230 or 230 to 400 mesh ASTM), Sephadex LH-20 (Amersham Pharmacia Biotech, Darmstadt, Hesse, Germany), and reversed-phase silica gel (ODS-A 12 nm S-150, S-75 $\mu$ m; YMC Co., Kyoto, Kansai, Japan) were used to perform open column chromatography. Tyrosinase (T3824) and L-tyrosine (T3754) were purchased from Sigma-Aldrich (St. Louis, MO, USA).

\subsection{Extraction and Isolation}

L. japonicus (5 kg) was extracted with $80 \%$ methanol at $27^{\circ} \mathrm{C}$. The concentrated methanol extract $(0.8 \mathrm{~kg})$ was suspended in distilled water and successively partitioned with $\mathrm{n}$-hexane, ethyl acetate, and aqueous layers. The ethyl acetate fraction $(73.1 \mathrm{~g})$ was subjected to silica gel column chromatography with a gradient of $n$-hexane-acetone gradient (from 10:1 $\rightarrow$ 1:100) to yield 20 fractions. E 18 fraction was purified with C-18 column chromatography with methanol gradient (from $30 \% \rightarrow 50 \%$ ) to give compound $3(72.1 \mathrm{mg})$. Compound 4 (21 mg) was purified by C-18 column chromatography with $50 \%$ methanol isocratic system from E 19 fraction. E 20 Fraction was chromatographied by C-18 column chromatography with 50\% methanol to gain six fractions (E201-206), and then E203 fraction was purified with Sephadex LH-20 column chromatography by using $40 \%$ methanol to obtain compounds $\mathbf{1}(15.1 \mathrm{mg}), \mathbf{2}(8.5 \mathrm{mg})$, and $\mathbf{5}(51.9 \mathrm{mg})$. The spectrum analysis is in the Supplementary Materials.

\subsection{Enzymatic Assay}

The enzyme assay was performed with spectrophotometer as described previously with a modified method [16]. Briefly, $130 \mu \mathrm{L}$ of tyrosinase in $0.05 \mathrm{mM}$ phosphate buffer (pH 6.8) and $20 \mu \mathrm{L}$ of the inhibitors dissolved in $\mathrm{MeOH}$ were added into a 96-well plate, and then mixed with $50 \mu \mathrm{L}$ of $\mathrm{L}$-tyrosine at $37^{\circ} \mathrm{C}$. The mixture was recorded at wavelength of $475 \mathrm{~nm}$ for $20 \mathrm{~min}$.

The inhibitory ratio was calculated according to the following equation:

$$
\text { Inhibitory activity rate }(\%)=[(\Delta \mathrm{C} / \Delta \mathrm{S}) / \Delta \mathrm{C}] \times 100
$$

where $\Delta C$ and $\Delta S$ represent the intensity of control and inhibitor after $20 \mathrm{~min}$, respectively.

$$
y=y_{0}+[(a \times x) /(b+x)]
$$

where $\mathrm{y}_{0}$ is the minimum value on the $\mathrm{y}$-axis, a denotes the difference between maximum and minimum values, and $b$ refers to the $x$ value at $50 \%$.

$$
1 / v_{0}=(K \mathrm{~m} / V \max )\left(1+[\mathrm{I}] / K_{\mathrm{i}}\right)(1 /[\mathrm{S}])+1 / V \max
$$


where $v_{0}$ represents the initial velocity, $V \max$ is the maximum rate at saturation of the substrate concentration, and $\mathrm{Km}$ is the substrate concentration [S] at which the reaction rate is half of $V$ max.

$$
1 / v_{0}=\left(K \mathrm{~m} / V \max [\mathrm{S}] K_{\mathrm{i}}\right)[\mathrm{I}]+1 / V \max (1+K \mathrm{~m} /[\mathrm{S}])
$$

where $K_{\mathrm{i}}$ is the inhibition constant of the inhibitor binding to the enzyme.

\subsection{Docking Simulation}

This study was performed as previously described [5]. The three-dimensional structure of tyrosinase was achieved from the file coded in 2Y9X from RCSB for docking simulation, and then water and substrate molecules in pdb file were deleted. The structure of inhibitors was constructed by the minimization with MM2. Pseudoalkaloids ( $\mathbf{1}$ and $\mathbf{2}$ ) were docked with the grid containing the activity site (number of points: $X: 80, Y: 80, Z: 80$ ) by Autodock 4.2. Docking of inhibitor into active site of protein was performed by using the Lamarckian Genetic Algorithm (runs: the maximum number of evals was set as long). The simulation results were prepared using Chimera and LigPlot.

\subsection{Data Analysis}

Data were expressed as the means \pm standard deviation $(n=3)$. All values were analyzed using SigmaPlot (Systat Software Inc., San Jose, CA, USA) to determine treatment variations.

\section{Results}

\subsection{Identification and Determination of the Tyrosinase Inhibitory Activity of Compounds}

Compounds 1-5 were isolated from L. japonicas by column chromatography. The structures were elucidated by nuclear magnetic resonance spectroscopy and compared with previously reported mass spectra. The compounds were determined to be 10-methoxy-leonurine (1) [17], leonurine (2) [17], syringic acid (3) [17], isoquercitrin (4) [18], and leonurusoide E (5) [18] (Figure 1).<smiles>[R]c1c(OC)cc(C(=O)OCCCCN=C(N)N)cc1OC</smiles><smiles>[R]c1c(-c2ccc(O)c(O)c2)oc2cc(O)cc(O)c2c1=O</smiles>

$1, \mathrm{R}=-\mathrm{OCH}_{3}$

2, $\mathrm{R}=-\mathrm{OH}$<smiles>COc1cc(C(=O)O)cc(OC)c1O</smiles>

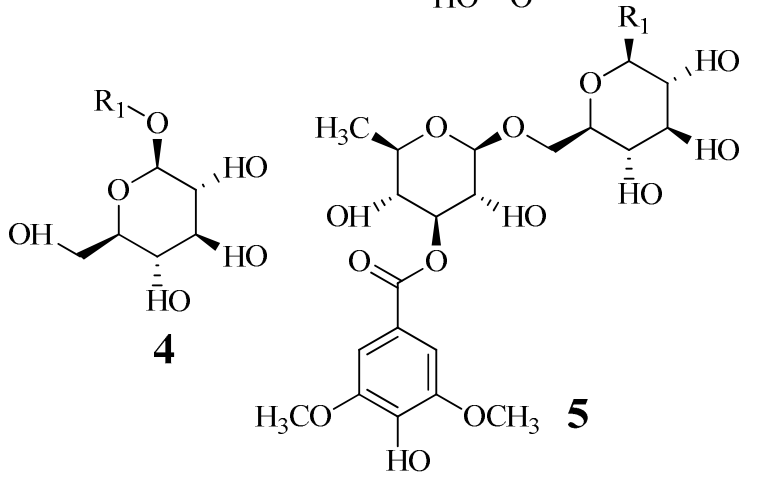

Figure 1. The structure of components 1-5 from Leonurus japonicas.

The tyrosinase inhibitory activities of compounds 1-5 were evaluated. To screen the isolated compounds, their tyrosinase inhibitory rates were evaluated at a compound concentration of $100 \mu \mathrm{M}$ and were then calculated using Equation (1). Compounds $\mathbf{1}$ and $\mathbf{2}$ showed greater than 80\% inhibitory activity, and $\mathrm{IC}_{50}$ values were determined (Figure $2 \mathrm{~A}$, Table 1 ). The dose-dependent inhibitory rates of 10-methoxy-leonurine (1) and leonurine (2) at concentrations ranging from 3.1 to $100 \mu \mathrm{M}$ were 
evaluated. Six inhibitory rates were input into Equation (2), and the $\mathrm{IC}_{50}$ of the inhibitor was defined when Equation (2) was equal to 50. The $\mathrm{IC}_{50}$ values of 10-methoxy-leonurine (1) and leonurine (2) were determined to be $7.4 \pm 0.4$ and $12.4 \pm 0.8 \mu \mathrm{M}$, respectively (Figure 2B, Table 1).
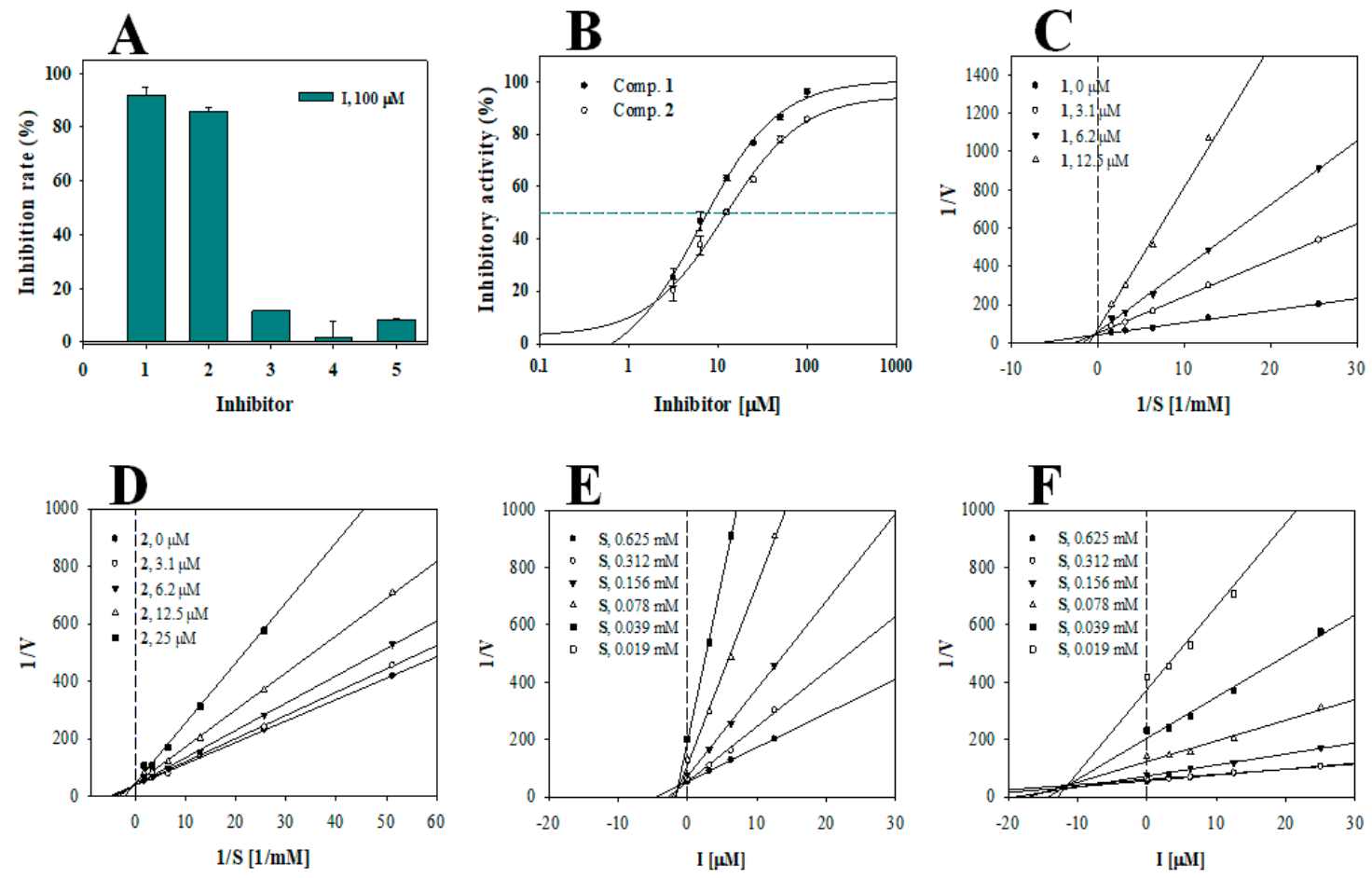

Figure 2. The inhibitory activities of compounds $\mathbf{1 - 5}$ at $100 \mu \mathrm{M}$ concentration toward tyrosinase (A). $\mathrm{IC}_{50}$ values (B), Lineweaver-Burk plots (C,D), Dixon plots (E,F) of two inhibitors $\mathbf{1}$ and $\mathbf{2}$, respectively.

Table 1. Inhibitory activity of isolated compounds 1-5 from L. japonicas toward tyrosinase.

\begin{tabular}{|c|c|c|c|}
\hline Inhibitor & $\begin{array}{c}\text { Inhibition Rate (\%) at } \\
\qquad 100 \mu \mathrm{M}^{\mathrm{a}}\end{array}$ & IC $_{50}$ Value $(\mu \mathrm{M})$ & Binding Type $\left(K_{i}, \mu \mathrm{M}\right)$ \\
\hline 1 & $91.8 \pm 2.9$ & $7.4 \pm 0.4$ & Competitive $(1.6 \pm 0.7)$ \\
\hline 2 & $85.6 \pm 1.8$ & $12.4 \pm 0.8$ & Competitive $(11.4 \pm 1.1)$ \\
\hline 3 & $11.6 \pm 0.1$ & N.T ${ }^{c}$ & N.T ${ }^{c}$ \\
\hline 4 & $1.8 \pm 5.9$ & N.T ${ }^{c}$ & N.T ${ }^{c}$ \\
\hline 5 & $8.3 \pm 0.6$ & N.T ${ }^{c}$ & N.T ${ }^{c}$ \\
\hline Kojic acid $^{\mathrm{b}}$ & $79.4 \pm 2.5$ & $25.7 \pm 1.3$ & \\
\hline
\end{tabular}

\subsection{Enzyme Kinetics}

To analyze the binding of the inhibitors to tyrosinase, 10-methoxy-leonurine (1) and leonurine (2) were subjected to enzyme kinetic analyses. The rate of substrate to product conversion via interactions of the substrate and inhibitor with tyrosinase is dependent on the concentrations of the substrate $(0.04-0.62 \mathrm{mM})$ and inhibitor. The initial velocity $\left(v_{0}\right)$ was induced within $15 \%$ of all conversion rates. The results are presented as a Lineweaver-Burk plot of $1 / v_{0}$ versus $1 /[\mathrm{S}]$ to determine the binding mechanism. 10-methoxy-leonurine (1) and leonurine (2) made a family line induced by Equation (3). As shown in Figure 2C,D, inhibitors 1 and 2 had different $-1 / K_{m}$ and $1 / V_{\max }$ values (Figure $2 C, D$, Table 1), suggesting that these compounds are competitive inhibitors. Furthermore, a Dixon plot using Equation (4) revealed that the inhibition constants $\left(K_{\mathrm{i}}\right)$ for inhibitors (1) and (2) were $1.6 \pm 0.7$ and $11.4 \pm 1.1 \mu \mathrm{M}$, respectively (Figure 2E,F, Table 1). 


\subsection{Molecular Docking}

Our enzyme kinetic analysis suggested that compounds (1) and (2) dock within the active site of tyrosinase. We performed molecular docking simulations using the Autodock 4.2 program to determine the binding site between ligand and receptor. They were attempted in the simulation into he grid containing active site 25,000,000 times. We then extracted and analyzed the top 50 Autodock scores (Figure 3A,B, Table 2). 10-methoxy-leonurine (1) had a cluster at approximately $-6.8 \mathrm{kcal} / \mathrm{mol}$, whereas leonurine (2) had two clusters at approximately -6.2 and $-6.1 \mathrm{kcal} / \mathrm{mol}$. The top $10 \mathrm{ranks}$ of the two inhibitors (1 and $\mathbf{2}$ ) were also analyzed (Figure 3C,D, Table 2).
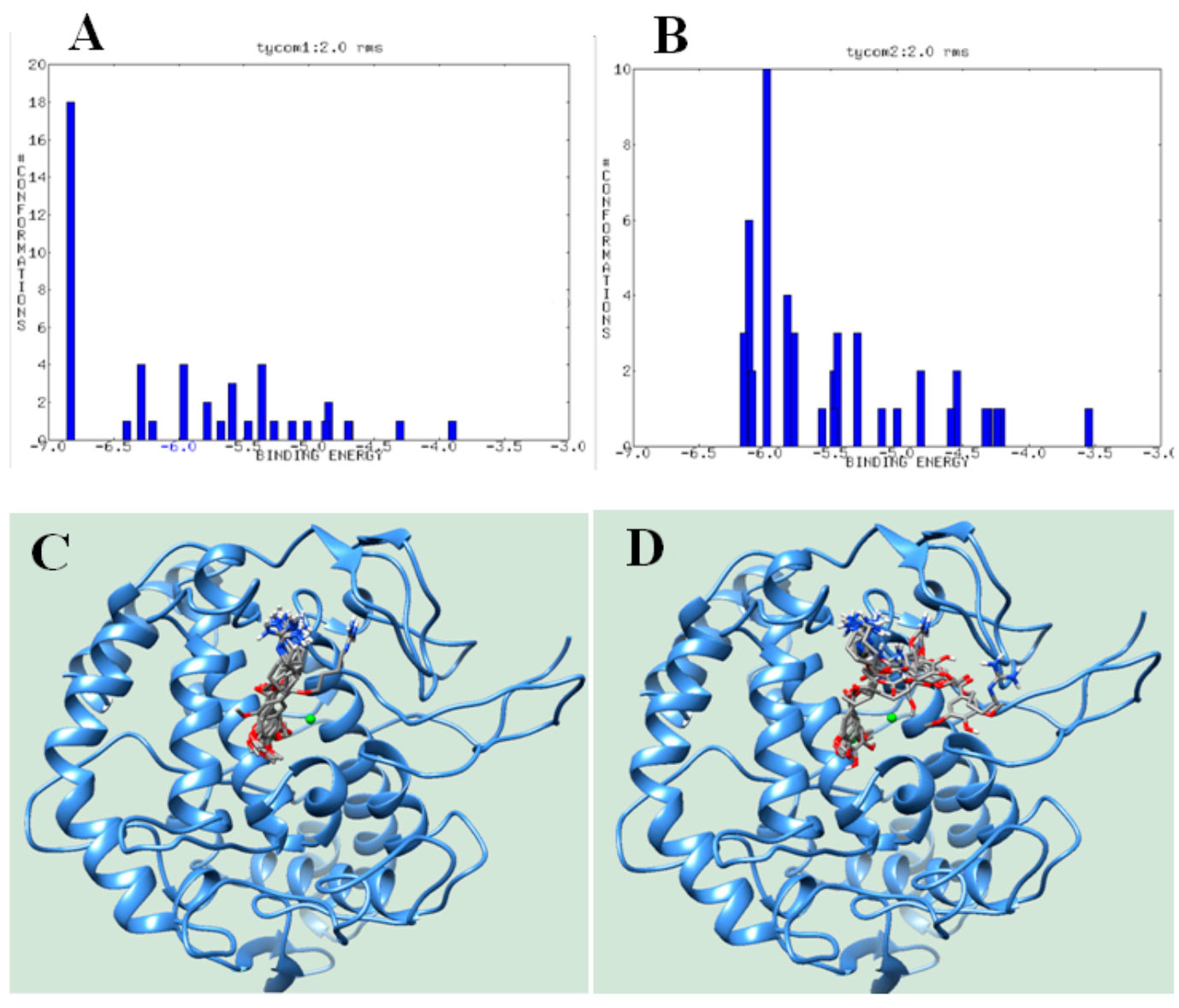

Figure 3. Cont. 
$\mathbf{E}$

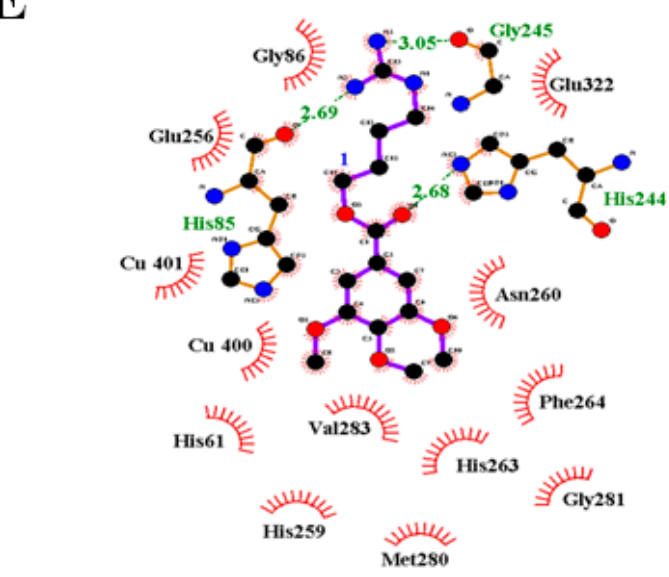

G

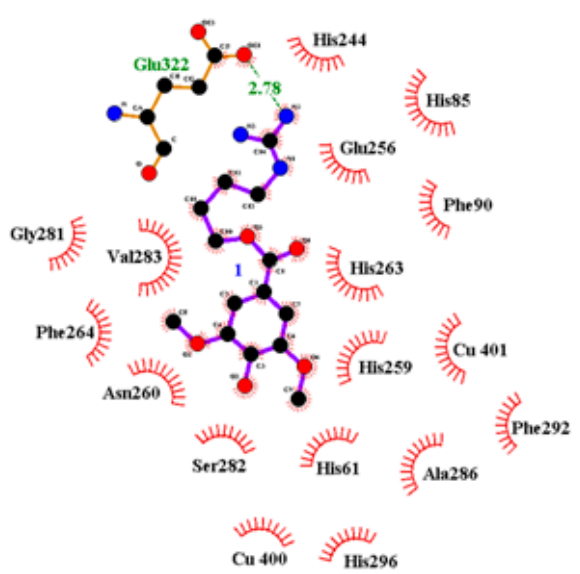

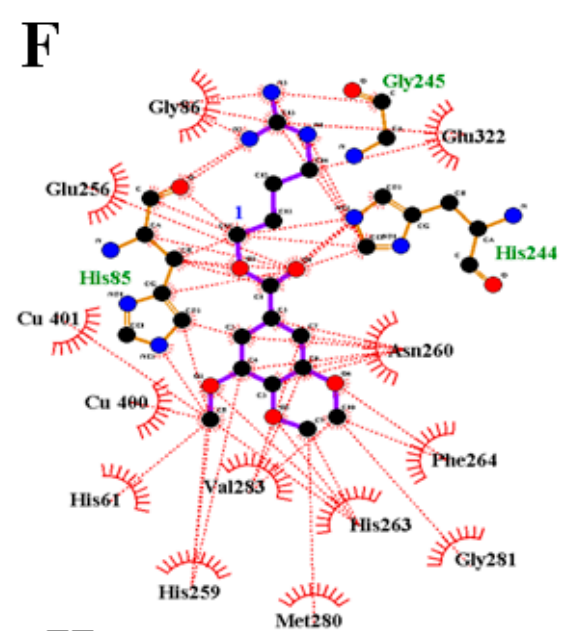

$\mathbf{H}$

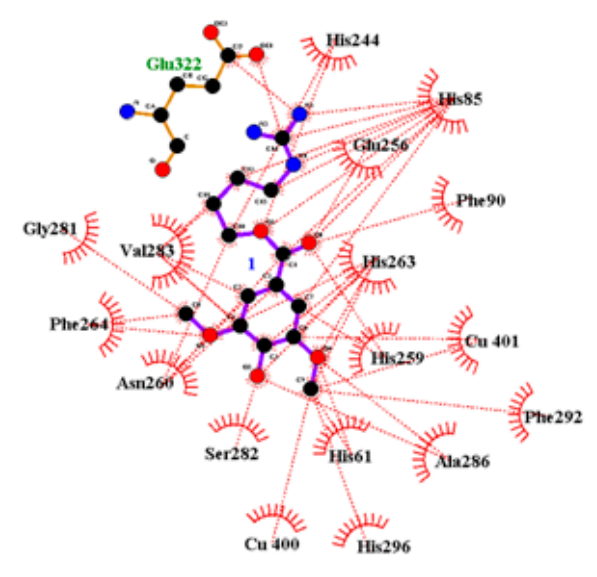

Figure 3. Cluster analysis of Autodock scores of inhibitors $\mathbf{1}$ and $\mathbf{2}$ into tyrosinase (A,B). The overlapped docking pose of the top 10 ranks (C,D). Hydrogen bonds (1: $(\mathbf{E}, \mathbf{G}))$ and hydrophobic interaction $(2:(\mathbf{F}, \mathbf{H}))$ at the best pose of the two docked into the catalytic site.

The lowest Autodock score $(-6.83 \mathrm{kcal} / \mathrm{mol})$ for 10-methoxy-leonurine (1) revealed three hydrogen bonds with His85 (2.69 ̊), His244 (2.68 ̊), and Gly245 (3.05 $)$ ) and hydrophobic interactions with 16 amino acids. In the simulation, leonurine (2) (Autodock score of $-6.16 \mathrm{kcal} / \mathrm{mol}$ ) maintained a distance of $2.78 \AA$ from Glu322 and interacted with 10 residues (Figure 3E-H, Table 2).

Table 2. Autodock scores and hydrogen bonds of the top 10 ranks between tyrosinase and inhibitors.

\begin{tabular}{|c|c|c|c|c|}
\hline \multirow{2}{*}{ Ranks } & \multicolumn{2}{|c|}{1} & \multicolumn{2}{|c|}{2} \\
\hline & $\begin{array}{l}\text { Autodock Score } \\
\text { (kcal/mol) }\end{array}$ & $\begin{array}{l}\text { Hydrogen Bonds } \\
\text { (Å) }\end{array}$ & $\begin{array}{l}\text { Autodock Score } \\
\text { (kcal/mol) }\end{array}$ & $\begin{array}{l}\text { Hydrogen Bonds } \\
\text { (A) }\end{array}$ \\
\hline 1 & -6.83 & $\begin{array}{l}\text { His85 (2.69), } \\
\text { His244(2.68), } \\
\text { Gly245(3.05) }\end{array}$ & -6.16 & Glu322(2.78) \\
\hline 2 & -6.82 & $\begin{array}{l}\text { His244(2.99), } \\
\text { Gly245(2.71) }\end{array}$ & -6.12 & Ala246(2.67) \\
\hline 3 & -6.78 & $\begin{array}{l}\text { His244(2.81), } \\
\text { Gly245(2.97) }\end{array}$ & -6.12 & $\begin{array}{l}\text { His244(3.01), } \\
\text { Ala246(2.67) }\end{array}$ \\
\hline 4 & -6.76 & $\begin{array}{l}\text { His244(2.91), } \\
\text { Gly245(2.65) }\end{array}$ & -6.1 & $\begin{array}{c}\text { Tyr78(3.07), } \\
\text { Asn81(2.98), } \\
\text { His85(2.50, 2.82) }\end{array}$ \\
\hline
\end{tabular}


Table 2. Cont.

\begin{tabular}{|c|c|c|c|c|}
\hline \multirow[b]{2}{*}{ Ranks } & \multicolumn{2}{|c|}{1} & \multicolumn{2}{|c|}{2} \\
\hline & $\begin{array}{l}\text { Autodock Score } \\
\text { (kcal/mol) }\end{array}$ & $\begin{array}{l}\text { Hydrogen Bonds } \\
\text { (Å) }\end{array}$ & $\begin{array}{l}\text { Autodock Score } \\
\text { (kcal/mol) }\end{array}$ & $\begin{array}{l}\text { Hydrogen Bonds } \\
\text { (Å) }\end{array}$ \\
\hline 5 & -6.60 & $\begin{array}{l}\text { His244(2.95), } \\
\text { Gly245(2.72) }\end{array}$ & -5.99 & $\begin{array}{c}\text { Asn81(2.64, 2.92), } \\
\text { His85(2.67, 3.26), } \\
\text { His244(3.02) }\end{array}$ \\
\hline 6 & -6.58 & Gly245(2.93) & -5.91 & $\begin{array}{l}\text { Asn81(2.84), } \\
\text { Cys83(2.67) } \\
\text { His85(3.01), } \\
\text { Gly86(2.88), }\end{array}$ \\
\hline 7 & -6.54 & $\begin{array}{l}\text { His85(2.82), } \\
\text { His244(2.99), } \\
\text { Glu322(2.56) }\end{array}$ & -5.85 & $\begin{array}{l}\text { His85(3.01), } \\
\text { Gly86(3.04), } \\
\text { Ala323(3.18) }\end{array}$ \\
\hline 8 & -6.52 & $\begin{array}{l}\text { His244(2.87), } \\
\text { Ala246(3.16) }\end{array}$ & -5.83 & $\begin{array}{l}\text { His85(3.03), } \\
\text { Asn320(2.96) }\end{array}$ \\
\hline 9 & -6.40 & $\begin{array}{l}\text { His85(3.05), } \\
\text { His244(3.14), } \\
\text { Asn320(3.01) }\end{array}$ & -5.80 & $\begin{array}{l}\text { His244(2.96), } \\
\text { Glu322(2.68) }\end{array}$ \\
\hline 10 & -6.38 & $\begin{array}{l}\text { His244(2.69), } \\
\text { Gly245(3.08), } \\
\text { Asn260(3.25) }\end{array}$ & -5.80 & $\begin{array}{l}\text { Asn81(2.63), } \\
\text { Cys83(3.14), } \\
\text { His85(2.85) }\end{array}$ \\
\hline
\end{tabular}

\section{Discussion}

The search for new tyrosinase inhibitors is of interest in medicinal, cosmetic, agricultural, and food industries $[6,19]$. Tyrosinase catalyzes the reactions that produce dihydroxyphenylalanine and dopaquinone in the initial steps of melanogenesis [20]. Diterpenes and methanol extracts from $L$. japonicus were shown to stimulate melanogenesis in B16F10 cells [15]. The guanidine pseudoalkaloid leonurine (2) was first identified in 1930 as an important compound of Leonurus sibiricus [21]; leonurine decreases the interleukin-1 $\beta$-induced expression of cyclooxygenase- 2 and inducible nitric oxide synthase, as well as activation of nuclear factor- $\mathrm{kB}$ p65 in chondrocytes [22].

Doxycycline-induced apoptosis of $\mathrm{H} 9 \mathrm{c} 2$ cells was studied to be protected and doxycycline-induced dissipation of $\Delta \Psi m$ was recovered by $10 \mu \mathrm{M}$ leonurine [23]. 10-Methoxy-leonurine (1) was first isolated from L. japonicas and reported to inhibit soluble epoxide hydrolases [17]. In this study, compounds 1 and $\mathbf{2}$ were identified as potential tyrosinase inhibitors that block the catalytic reactions of tyrosinase at approximately $10 \mu \mathrm{M}$. Upon binding to tyrosinase, both inhibitors blocked the interaction of the substrate with the tyrosinase active site. Molecular simulation is one of the essential methods for drug development by providing a clue to the ligand-receptor interaction by theoretical computational chemistry [24,25]. According to the molecular docking, the guanidine group occupied the cavity by three loops (Asn243 to er254, Gly62 to Leu89, and Arg321 to Gly330). Keton of ester in (1) was tied within $3.5 \AA$ by His 244 , and the aromatic ring was anchored within the inner active site via hydrophobic interactions only. As a result, inhibitor (1) occupied a stable position extending from the cavity to the active site, whereas the hydroxyl group of the aromatic ring in (2) formed hydrogen bonds with His85, Asn81, Cys83, and Ala323, according to the top 10 ranks. The guanidine group of (2) was hung on the cavity of three loops, and the aromatic ring docked within the active site or the other. These findings likely explain the greater inhibitory activity of 10-methoxy-leonurine (1) than leonurine (2). Further studies will be necessary to increase the hydrophobicity of the aromatic ring of guanidine pseudoalkaloids for the development of novel tyrosinase inhibitors.

\section{Conclusion}

To identify novel tyrosinase inhibitors from plants, we prepared pure components from L. japonicas. Five compounds (1-5) were tested for their inhibitory activity against tyrosinase. The guanidine pseudoalkaloids 10-methoxy-leonurine (1) and leonurine (2) exhibited inhibitory activity against tyrosinase, with $\mathrm{IC}_{50}$ values of $7.4 \pm 0.4$ and $12.4 \pm 0.8 \mu \mathrm{M}$, respectively. Based on enzyme kinetics and 
molecular docking, both compounds appear to operate as competitive inhibitors by locking the active site of the enzyme. In conclusion, compound (1), with a $K_{\mathrm{i}}$ value of $1.6 \pm 0.7 \mu \mathrm{M}$, is a potential tyrosinase inhibitor, and guanidine pseudoalkaloids may be useful as lead compounds for the development of new tyrosinase agents.

Supplementary Materials: The following are available online at http://www.mdpi.com/2218-273X/10/2/174/s1, Figure S1-S10: ${ }^{1} \mathrm{H}-\mathrm{NMR},{ }^{13} \mathrm{C}-\mathrm{NMR}$ spectrum ESI-MS spectrum of compound 1-5.

Author Contributions: Conceptualization, G.Y.L. and J.H.K.; methodology, J.H.K.; validation, J.H.K. and, H.H.L.; formal data curation, J.H.K. and H.H.L.; writing—original draft preparation, J.H.K; writing—review and editing, G.Y.L. All authors have read and agreed to the published version of the manuscript.

Funding: This research was supported by Basic Science Research Program through the National Research Foundation of Korea (NRF) funded by the Ministry of Education (2019R1A6A1A10072987).

Conflicts of Interest: The authors declare no conflict of interest.

\section{References}

1. Fan, M.; Ding, H.; Zhang, G.; Hu, X.; Gong, D. Relationships of dietary flavonoid structure with its tyrosinase inhibitory activity and affinity. LWT-Food Sci. Technol. 2019, 107, 25-34. [CrossRef]

2. Gui, L.; Lee, J.h.; Hao, H.; Park, Y.-D.; Zhan, Y.; Lü, Z.-R. The effect of oxaloacetic acid on tyrosinase activity and structure: Integration of inhibition kinetics with docking simulation. Int. J. Biol. Macromol. 2017, 101, 59-66.

3. Carcelli, M.; Rogolino, D.; Bartoli, J.; Pala, N.; Compari, C.; Ronda, N.; Bacciottini, F.; Incerti, M.; Fisicaro, E. Hydroxyphenyl thiosemicarbazones as inhibitors of mushroom tyrosinase and antibrowning agents. Food Chem. 2020, 303, 125310. [CrossRef] [PubMed]

4. Zeng, H.-J.; Liu, Z.; Hu, G.-Z.; Qu, L.-B.; Yang, R. Investigation on the binding of aloe-emodin with tyrosinase by spectral analysis and molecular docking. Spectrochim. Acta. A Mol. Biomol. Spectrosc. 2019, 211, $79-85$. [CrossRef] [PubMed]

5. Dehghani, Z.; Khoshneviszadeh, M.; Khoshneviszadeh, M.; Ranjbar, S. Veratric acid derivatives containing benzylidene-hydrazine moieties as promising tyrosinase inhibitors and free radical scavengers. Bioorg. Med. Chem. Lett. 2019, 27, 2644-2651. [CrossRef] [PubMed]

6. Cásedas, G.; Les, F.; González-Burgos, E.; Gómez-Serranillos, M.P.; Smith, C.; López, V. Cyanidin-3-O-glucoside inhibits different enzymes involved in central nervous system pathologies and type-2 diabetes. S. Afr. J. Bot. 2019, 120, 241-246. [CrossRef]

7. Tian, J.-L.; Liu, T.-L.; Xue, J.-J.; Hong, W.; Zhang, Y.; Zhang, D.-X.; Cui, C.-C.; Liu, M.-C.; Liu, S.-L. Flavanoids derivatives from the root bark of Broussonetia papyrifera as a tyrosinase inhibitor. Ind. Crop. Prod. 2019, 138, 111445. [CrossRef]

8. Wagle, D.; Seong, S.H.; Jung, H.A.; Choi, J.S. Identifying an isoflavone from the root of Pueraria lobata as a potent tyrosinase inhibitor. Food Chem. 2019, 276, 383-389. [CrossRef]

9. Tan, Y.-J.; Xu, D.-Q.; Yue, S.-J.; Tang, Y.-P.; Guo, S.; Yan, H.; Zhang, J.; Zhu, Z.-H.; Shi, X.-Q.; Chen, Y.-Y.; et al. Comparative analysis of the main active constituents from different parts of Leonurus japonicus Houtt. and from different regions in China by ultra-high performance liquid chromatography with triple quadrupole tandem mass spectrometry. J. Pharm. Biomed. Anal. 2020, 177, 112873. [CrossRef]

10. Zhong, W.-M.; Cui, Z.-M.; Liu, Z.-K.; Yang, Y.; Wu, D.-R.; Liu, S.-H.; Long, H.; Sun, H.-D.; Dang, Y.-J.; Xiao, W.-L. Three minor new compounds from the aerial parts of Leonurus japonicas. Chinese Chem. Lett. 2015, 26, 1000-1003. [CrossRef]

11. Li, H.-Y.; Peng, X.; Jin, X.J.; Wei, W.-J.; Ma, K.-L.; Li, Y.; Chen, J.-J.; Gao, K. Labadane-type diterpenoids from Leonurus japonicus and their plant-growth regulatory activity. J. Nat. Prod. 2019, 82, 2568-2579. [CrossRef] [PubMed]

12. Li, Y.; Chen, Z.; Feng, Z.; Yang, Y.; Jiang, J.S.; Zhang, P.C. Hepatoprotective glycosides from Leonurus japonicas Houtt. Carbohydr. Res. 2012, 348, 42-46. [CrossRef]

13. Zhou, Q.-m.; Peng, C.; Yang, H.; Liu, L.-S.; Yang, Y.-T.; Xie, X.-F.; Guo, L.; Liu, Z.-H.; Xiong, L. Steroids from the aerial parts of Leonurus japonicus. Phytochem. Lett. 2015, 12, 287-290. [CrossRef] 
14. Liu, J.; Peng, C.; Zhou, Q.-M.; Guo, L.; Liu, Z.-H.; Xiong, L. Alkaloids and flavonoid glycosides from the aerial parts of Leonurus japonicas and their opposite effects on uterine smooth muscle. Phytochemistry 2018, 145, 128-136. [CrossRef]

15. Lai, K.-Y.; Hu, H.-C.; Chiang, H.-M.; Liu, Y.-J.; Yang, J.-C.; Lin, Y.-A.; Chen, C.-J.; Chang, Y.-S.; Lee, C.-L. New diterpenes leojaponins G-L from Leonurus japonicas. Fitoterapia 2018, 130, 125-133. [CrossRef]

16. Santi, M.D.; Bouzidi, C.; Gorod, N.S.; Puiatti, M.; Michel, S.; Grougnet, R.; Ortega, M.G. In vitro biological evaluation and molecular docking studies of natural and semisynthetic flavones from Gardenia oudiepe (Rubiaceae) as tyrosinase inhibitors. Bioorg. Chem. 2019, 82, 241-245. [CrossRef] [PubMed]

17. Leem, H.H.; Lee, G.Y.; Lee, J.S.; Lee, H.N.; Kim, J.H.; Kim, Y.H. Soluble epoxide hydrolase inhibitory activity of components from Leonurus japonicas. Int. J. Biol. Macromol. 2017, 103, 451-457. [CrossRef]

18. Wang, L.; Yang, X.; Qin, P.; Shan, F.; Ren, G. Flavonoid composition, antibacterial and antioxidant properties of tartary buckwheat bran extract. Ind. Crops. Prod. 2013, 49, 312-317. [CrossRef]

19. Ghafary, S.; Ranjbar, S.; Larijani, B.; Amini, M.; Biglar, M.; Mahdavi, M.; Bakhshaei, M.; Khoshneviszadeh, M.; Sakhteman, A.; Khoshneviszadeh, M. Novel morpholine containing cinnamoyl amides as potent tyrosinase inhibitors. Int. J. Biol. Macromol. 2019, 135, 978-985. [CrossRef]

20. D’Mello, S.A.N.; Finlay, G.J.; Baguley, B.C.; Askarian-Amiri, M.E. Signaling pathways in melanogenesis. Int. J. Mol. Sci. 2016, 147, 1144. [CrossRef]

21. Kong, Y.C.; Yeung, H.W.; Cheung, Y.M.; Phil, M.; Hwang, J.C.; Chan, Y.W.; Law, Y.P.; Ng, K.H.; Yeung, C.H. Isolation of the uterotonic principle from Leonurus artemisia, the Chinese Motherwork. Am. J. Chin. Med. 1976, 4, 373-382. [CrossRef] [PubMed]

22. Yin, W.; Lei, Y. Leonurine inhibits IL-1 $\beta$ induced inflammation in murine chondrocytes and ameliorates murine osteoarthritis. Int. Immunopharmacol. 2018, 65, 50-59. [CrossRef] [PubMed]

23. Xin, H.; Liu, X.H.; Zhu, Y.Z. Herba leonurine attenuates doxorubicin-induced apoptosis in H9c2 cardiacmuscle cell. Eur. J. Pharmacol. 2009, 612, 75-79. [CrossRef] [PubMed]

24. Pradeepkiran, J.A.; Reddy, P.H. Structure based design and molecular docking studies for phosphorylated tau inhibitors in Alzheimer's disease. Cells 2019, 8, 260. [CrossRef] [PubMed]

25. Pradeepkiran, J.A.; Reddy, A.P.; Reddy, P.H. Pharmacophore-based models fro therapeutic drugs against phosphorylated tau in Alzheimer's disease. Drug Discov. Today 2019, 24, 616-623. [CrossRef] [PubMed]

(C) 2020 by the authors. Licensee MDPI, Basel, Switzerland. This article is an open access article distributed under the terms and conditions of the Creative Commons Attribution (CC BY) license (http://creativecommons.org/licenses/by/4.0/). 